\title{
How Socio-economic Status Affects Academic Performance
}

\section{A Study of Education Inequality in Junior High School Students in China Based on a Structural Equation Model}

\author{
Yuchen Jiang ${ }^{1, *}$ \\ ${ }^{1}$ School of Social and Political Science, University of Edinburgh, United Kingdom \\ *Corresponding author Email: s1950930@ed.ac.uk
}

\begin{abstract}
As social stratification has deepened in contemporary Chinese society, educational capital and academic performance in secondary education have differentiated according to students' socio-economic status. Most of the existing studies on the relationship between family background and children's academic achievement focus on the impact of a student's family background on the final level of education achieved, but education acquisition is a continuous process. Without an analysis of the educational process, it is difficult to understand the process mechanism by which family background affects children's educational opportunity. By using data from the China Education Panel Survey (CEPS), this paper studies the paths and effects of students' socio-economic status on their academic performance. Through modelling latent variables (socio-economic status, academic performance) with fourteen observed variables in a sample size of approximately 7,000 junior high school students around China, this study found that: first, families use their socioeconomic resources to provide children with different educational resources and thus influence their academic performance; second, through parents' educational participation and behavioural support, families develop children's learning attitudes and habits, thus influencing their academic achievements. The findings of this paper provide a possible basis for reducing class differences in children's academic achievements and promoting educational equity.
\end{abstract}

Keywords: Socio-economic status, academic performance, structural equation model, China

\section{INTRODUCTION}

Education is fundamental for the development of national quality, and education in childhood is the basis for the cultivation of a country's labour force. The acquisition of education in childhood not only affects individual's own sense of achievement and happiness, but also affects the quality and innovation of a country's labour force at the national level. Education thus affects nation's development ability [1]. In China, as compulsory education has become more widespread and schools have expanded in size, the average education level of residents has been significantly improved. Nevertheless, due to the scarcity of educational resources and their uneven allocation, there is still a great deal of room to improve educational inequality[2]. For this reason, the state council approved the "Outline of the National Medium- and Long-Term Programme for Education Reform and Development" in 2010 and set "promoting fairness in education and ensure equitable education for the benefit of all" as one of the key strategic goals of national education development.

On the one hand, the fairness of education is rooted in the institutional arrangement, which in turn cushions or even restrains the influence of families' socio-economic status. On the other hand, fair access to education relies on the opportunity and ability to participate in education. Either way, the ultimate outcome is the academic performance of the child within the peer group. In this way, the relationship between family background and access to education has become one of the most important indicators to measure the fairness of education. Research shows that since China's reform and opening up, the role of families' socio-economic status in individual education acquisition has been on the rise and, moreover, its influence has not weakened as school enrolment has expanded[3][4][5][6]. Most of the existing studies on the relationship between family background and children's 
academic achievement focus on the impact of a student's family background on the final level of education achieved, but it is worth noting that educational acquisition is a continuous process. The levels of achievement a student can reach in any given stage rely on gains in previous stages. Without access to quality primary and secondary education, there is little opportunity to enter higher education. Due to the cumulative nature of education, competition for educational resources begins already in primary and middle schools, and even kindergartens. Therefore, the lack of analysis of education as a process makes it difficult to understand the process mechanism by which family backgrounds affect children's access to educational resources and their eventual academic achievements. Finally, exploring the relationship between academic performance and family background from the starting point, that is, the compulsory education stage, has direct policy implications.

The goal of compulsory education is to ensure fair access to the starting point of education. Its compulsory and inclusive nature should theoretically minimize the impact of family background on children's access to educational resources. In the current Chinese education system, however, the relative scarcity of educational resources in high schools and universities has made academic achievement the main criterion for educational selection. Students' educational attainment is closely related to their academic performance at every stage. Therefore, the fairness of junior high school is not only reflected in the undifferentiated admission resources, but also reflected in the academic achievements of students, independently of family background.

In fact, in the stage of junior high school education, it is not only the differentiation of school classification (specifically, key schools and non-key schools) that will affect the students' academic achievement. Rather, parents' ability to participate in compulsory education will directly affect students' academic achievement. In contrast to previous studies that focused on the influence of family background on final education acquisition, this paper aims to explore the mechanism and path through which family background affects the academic achievement of children in junior high school.

\section{LITERATURE REVIEW}

Research on the influence of family background on academic achievement in foreign countries has a long history. In the United Kingdom, Galton began to explore the impact of parents' occupation on students' education as early as 1874 [7]. The most representative study on family background and academic achievement was conducted by the American sociologist Coleman. His team's research report "Equal Educational Opportunity", published in 1966, surveyed 640,000 primary and middle school students in the United States. Coleman and his team found that the two important factors that caused differences in students' academic performance were students' intelligence and their family background[8].

Since then, scholars have continued to conduct numerous studies on this topic. In 1969, Kiesling conducted a survey and analysis of sixth-grade students from 97 areas of New York State. His results showed that parents' occupations were positively related to students' mathematics performance: the higher the parents' professional status, the better scores the students' achieved in maths[9]. In 1972, Jencks and his colleagues found that factors related to students' family, especially the socio-economic status of the family, can explain the differences in students' academic achievements better than school factors [10]. They believed that family factors can account for more than half of the differences in academic achievement, while school factors have little contribution to eliminating inequality in academic achievement. In 1976, Swell and Hauser proposed that, although family socio-economic status has a strong positive correlation with academic performance, it does not provide a simple and direct impact. Rather, educational improvement requires the participation and interaction of parents to act as an intermediary[11]. At the same time, they found that parents' expectations have a great effect on their children's academic performance. Datcher-Loury's research in 1988 showed that parents educational behaviours and attitudes, such as reading, guiding their children, and setting high educational expectations for their children have obvious and longterm effects on children's academic achievements[12].

Apart from parents' educational expectations, parentchild interaction in the family is also an important way in which the family environment affects students' academic performance. Many studies have shown that parents' participation in students' learning largely mediates the influence of socio-economic status on academic performance. In 1982, Laosar's research also proved the influence of socio-economic status on parent-child relationships. He believed that parent-child interaction is an intermediary variable between socio-economic variables and student academic performance[13]. Levinni explained that socio-economic status has a great influence on the academic performance of a child because different environments exist within different social classes[14]. For example, middle-class families may choose to live near the best school or send their children to the best schools. These different environments will affect the intellectual development and learning motivation of their children in different ways so that these children from middle-class families will be well prepared for good academic performance.

Chinese scholars have also conducted a lot of research on the relationship between family background and academic achievement in the Chinese context. The main aspects of research address the following questions: 
Children in what kind of family are more likely to achieve academic success? What factors in the family have an impact on children's academic achievements? How do family factors affect children's academic achievements?

Yang Dongping's research is one of the most representative explorations. He believes that children from families with higher economic and social status, and higher educational level, are more likely to achieve academic success themselves. As he points out, "the class gap in higher education entrance opportunities is not only reflected in the rate of children of different classes entering colleges and universities, but also in their distribution in the higher education system. There are significant differences in the distribution of students from different family backgrounds in different levels of colleges and universities. The children of parents working in management positions, as professional technicians, and intellectuals who have access to more cultural and social capital, account for a larger proportion in key national universities. In key universities, the number of children of state management personnel is 17 times the number of children of unemployed parents from urban and rural areas. At different educational levels, generally superior classes with a stronger cultural and social capital obtain more educational opportunities"[15].

Many scholars from China have analysed how family factors influence academic achievement. For example, in the 1980s, Chinese scholars Ding and Wu conducted research on primary and secondary school students in mainland China. Their results showed that students' family background, including economic status, parents' occupation, cultural level, family environment, and parental expectations, are significantly related to the students' academic achievements [16]In 2000, Lu conducted a nationwide survey of 2,432 students from middle school, high school, and university that explored the influence of family factors on students' academic performance. The results showed that academic performance is closely related to parents' education levels, parents' occupations, and family income [17].

How do these factors affect students' academic achievement? Many scholars from China have discussed this important question. Dong, for example, believes that the family's material environment, spiritual atmosphere, and parenting methods have an important impact on students' academic success. In their view, the material environment provides the necessary material basis for students' academic success, the spiritual atmosphere creates a healthy psychological environment for the academic success of students, while parenting methods are the key factors for academic success [18]. In The State, Social Class and Education, Liu argues that the relative advantages of class are more obvious in the competition of status-oriented educational opportunities but notes that classes with stronger capital advantages are less involved in the competition of survival-oriented educational opportunities. Class competition for statusoriented education opportunities has become fiercer since China's reform. These class advantages have been accumulated and magnified through access to secondary education. Survival-oriented education, meanwhile, has been severely blocked in the higher education stage. In the selective stage of education that is based on test selection skills, the advantages of cultural capital are more obvious, while the advantages of power capital are more subtle [19].

Yang pointed out that the educational level of parents has a direct impact on the family's cultural conditions, family atmosphere, and parent-child communication, and that each of these factors has a positive effect on children's learning efficiency and effectiveness [20]. Under certain circumstances, social capital, economic capital, and cultural capital can transform into each other. Families with a higher socio-economic status are more likely to obtain rare educational opportunities for their children through their social networks. Social capital thus plays an important role in students' choice of school and class, thereby affecting students' academic achievement. Another indicator of family social capital is whether the parents are familiar with the classroom teacher and whether they have acquaintances at the school. $\mathrm{Yu}$ and Luo believe that the difference in class is evident through the students' academic achievements. They argue that family cultural capital has very strong characteristics of inter-generational inheritance which will directly affect the children's academic achievements. Family economic capital and social capital, meanwhile, affect children's choices of educational resources and therefore influence the academic achievement of the next generation [21]. More recently, $\mathrm{Li}$ and Qiu studied data from the China Family Panel Study in 2016 and provided empirical evidence on the path and impact of family background on academic performance [22].

Since the 1960s, the results of a large number of studies on the relationship between family background and academic performance, carried out in China and abroad, show that the family is one of the most important learning environments that affect students' academic achievement. Through the collection and evaluation of relevant literature, it is revealed that many factors in the family have an impact on academic achievement. The main factors of family environment frequently used to predict students' academic achievement are: 1. The material conditions of the family; 2 . the atmosphere of the family (tense or harmonious); 3. Parenting methods and styles (democracy or autocracy); 4. Interaction between parents and children; 5. Types of shared parent-child activities (such as work, reading, watching movies, etc.); 6. Parents' attitude towards school, interest in children's performance at school, and contact with school or 
teachers; 7. Family education plans; 8. Parents' expectations for children.

\section{ANALYSIS FRAMEWORK}

By analysing existing literature and combining these findings with the reality of Chinese education, this paper proposes the following analysis framework (figure 1).

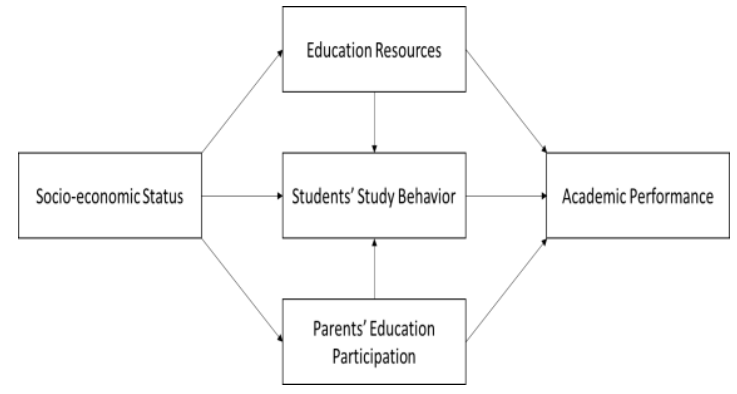

Figure 1 Analysis framework

Based on Li and Qiu's framework, the paper posits that the influence of family socio-economic status on children's academic performance is not direct but realized through two key paths. First, families with higher socioeconomic status strive for quality educational resources for their children (e.g., educational services provided by key schools and markets within the system), which in turn affect children's academic achievement. The monopoly of high-quality teachers and students in key schools not only directly leads to differences in children's academic achievements, but also influences their learning attitudes and behaviours due to interactions with teachers and peers. This process then influences children's academic achievements and the acquisition of educational resources in the next stage.

In addition, the development of the education and training market in primary and secondary schools provides alternatives and supplements to school education. Families with better economic conditions can buy additional educational products and services for their children, such as tutoring and remedial classes, thus strengthening the influence of family socio-economic status on children's academic achievement. Second, according to the theory of cultural and social capital, family socio-economic status affects the amount of effort children put into their studies and academic performance. To some extent, parents' educational expectations and behavioural support for their children are also affected by their socio-economic status. Varying levels of family resources and the abilities of families from different classes cause significant disparity in the types of educational support that can be provided. Families of higher socio-economic status attach more importance to the education of their children. As a result, these parents' support for their children's education, such as checking homework, discussing school conditions, etc, can cultivate children's learning habits and affect their academic performance.

\section{HYPOTHESIS}

Based on our analytical framework, we propose five hypotheses in this study.

Hypothesis 1: Families' socio-economic status plays an important role in determining the quality of education resources students can access. Students from families with high socio-economic status have access to higher quality education resources.

Hypothesis 1a: The higher the socio-economic status of the family, the better the quality of their child's school.

Hypothesis 1b: The higher the socio-economic status of the family, the more educational services are available to their children in the marketplace.

Hypothesis 2: Parents' participation in their children's education is influenced by their socio-economic status. Families with higher socio-economic status participate in their children's education more readily.

Hypothesis 3: Parents' educational participation and children's access to educational resources will influence children's learning attitudes and behaviours.

Hypothesis 3a: When parents are more involved in education, their children will be more active in learning.

Hypothesis 3b: When children attend a better school, they will have more active study effort.

Hypothesis 3c: The more educational services a child receives, the more effort they will put into their studies.

Hypothesis 4: The quality of education resources and parents' participation affects students' academic performance.

Hypothesis 4a: The better the schools the children attend, the better their academic performance

Hypothesis 4b: Greater access to marketable educational services raises children's academic performance

Hypothesis 4c: The higher the level of parental involvement, the better the children's academic performance.

Hypothesis 5: Students' personal study effort is crucial for their academic performance. Students' study effort will positively affect their academic performance. 


\section{REARCH METHODS}

\subsection{Data}

This paper draws on the Baseline Survey (2013) of the China Education Panel Study (CEPS) which was conducted by the National Survey Research Centre (NSRC) at Renmin University of China. Student Questionnaires and Parent Questionnaires are used in this paper. The CEPS applies a stratified, multistage sampling design with probability proportional to size (PPS), randomly selecting a school-based, nationally representative sample of approximately 20,000 students in 438 classrooms of 112 schools in 28 county-level units in mainland China. The sampling process of the CEPS can be divided into four phases. In Phase I of sampling, the administrative units at the county (district) level are used as Primary Sampling Unit (PSU). 28 counties (districts) are selected nationally. Considering the complexity and disparity of China's society, counties (districts) with different levels of economic development and population structure are taken into account. In Phase II of sampling, the school is taken as the Secondary Sampling Unit (SSU). Among counties (districts) selected in Phase I, 4 schools from each county (district) are extracted. In Phase III the class is taken as the Tertiary Sampling Unit (TSU), and the sampling of this phase is completed by the local cooperative units prior to the start of the field investigation. If there are only 1 class or 2 classes in the grade of the sample school, all classes will be included; if there are 3 or more classes in the grade of the sample school, 2 classes will be selected using the random number table in the class sample page. Upon completion of Phase III of the class sampling, all the students in the class surveyed were enrolled in the sample. This consists of Phase IV of the sampling.

The object of this study is students in grades 7 and 9 across China. In order to connect students' academic performance with an assessment of family capital, student questionnaires are paired with parents' questionnaires. After cleaning samples for missing values, we eventually achieved 6972 samples from 19487 original samples.

\subsection{Measurement}

Students' socio-economic status is one of the core explanatory variables in this study. The research uses four indicators: mother's education, father's education, mother's occupation, and father's occupation. Academic performance is measured using students' mid-term exam results. In order to ensure the reliability of this data, students' examination results are directly provided by schools rather than by students themselves. Also, the CEPS standardized students' examination results to allow nation-wide comparison. Standardized scores are calculated in accordance with students' grades and schools, and are adjusted into scores with a mean of 70 and standard deviation of 10 .

The quality of the school children attend has an important influence on their study efforts and academic achievement. Li and Qiu measured school quality by using parent's subjective judgements of schools. This method to some extent fails to capture the objectivity of school quality. As an improvement, we used three methods to measure school quality: overall regional ranking, the ratio of teachers with senior professional titles, and the condition of schools' facilities. Parents' participation is an important factor that affects students' academic performance. This paper used three measures to judge the level of parents' education participation: frequency of checking-up, instructing homework, and discussing things that happened in school with children. We used three questions from the student questionnaire to measure study effort. These are, "I would try my best to go to school even if I had any reasons to stay at home," "I would try my best to finish even the homework I dislike," and "I would try my best to finish my homework, even if it is time-consuming." Students' access to education services is measured by whether they attend cram school as well as the cost of cram school. The detailed measurement of these variables can be found in table 1 .

Table 1. Measurement of variables

\begin{tabular}{|c|c|c|}
\hline $\begin{array}{l}\text { Latent } \\
\text { Variable }\end{array}$ & $\begin{array}{l}\text { Variable } \\
\text { Name }\end{array}$ & $\begin{array}{l}\text { Observed Variable } \\
\text { Measurement }\end{array}$ \\
\hline \multirow{3}{*}{$\begin{array}{l}\text { Academic } \\
\text { Performance } \\
(\mathrm{AP})\end{array}$} & Y1 & Chinese Exam Result \\
\hline & Y2 & $\begin{array}{l}\text { Mathematics Exam } \\
\text { Result }\end{array}$ \\
\hline & Y3 & English Exam Result \\
\hline \multirow{4}{*}{$\begin{array}{l}\text { Education } \\
\text { Service } \\
\text { (ES) }\end{array}$} & \multirow{3}{*}{ Y4 } & Cram School \\
\hline & & $1=\mathrm{No}$ \\
\hline & & $2=$ Yes \\
\hline & Y5 & $\begin{array}{l}\text { Total cost of cram } \\
\text { school }\end{array}$ \\
\hline \multirow{11}{*}{$\begin{array}{l}\text { School } \\
\text { Quality } \\
\text { (SQ) }\end{array}$} & Y6 & Senior teacher ratio \\
\hline & \multirow{6}{*}{ Y7 } & $\begin{array}{l}\text { School regional } \\
\text { Ranking }\end{array}$ \\
\hline & & $1=$ Near the bottom \\
\hline & & 2=Below Average \\
\hline & & $3=$ Average \\
\hline & & 4=Above average \\
\hline & & $5=$ Among the best \\
\hline & \multirow[t]{4}{*}{ Y8 } & $\begin{array}{l}\text { School Facilities } \\
\text { (laboratory, computer } \\
\text { room, library, music } \\
\text { room, student activity } \\
\text { room, psychological } \\
\text { counselling room, } \\
\text { student cafeteria, } \\
\text { playground, } \\
\text { gymnasium, swimming } \\
\text { pool) }\end{array}$ \\
\hline & & $1=$ No \\
\hline & & $\begin{array}{l}2=\text { Yes, but need to be } \\
\text { improved }\end{array}$ \\
\hline & & $\begin{array}{l}3=Y e s, \text { and well } \\
\text { equipped }\end{array}$ \\
\hline
\end{tabular}




\begin{tabular}{|c|c|c|}
\hline \multirow{9}{*}{$\begin{array}{l}\text { Parent } \\
\text { Participation } \\
(P P)\end{array}$} & \multirow{5}{*}{$\begin{array}{l}\text { Y9 \& } \\
\text { Y10 }\end{array}$} & $\begin{array}{l}\text { Giving instruction on } \\
\text { homework every week } \\
\text { \& Checking-up } \\
\text { homework }\end{array}$ \\
\hline & & $1=$ Never \\
\hline & & $2=$ One or two days \\
\hline & & $3=$ Three or four days \\
\hline & & 4=Almost everyday \\
\hline & \multirow{4}{*}{$\mathrm{Y} 11$} & $\begin{array}{l}\text { Discus with children } \\
\text { about things happened } \\
\text { at school }\end{array}$ \\
\hline & & $1=$ Never \\
\hline & & $2=$ Sometimes \\
\hline & & $3=$ Often \\
\hline \multirow{15}{*}{$\begin{array}{l}\text { Study Effort } \\
\text { (SE) } \\
\text { Socio- } \\
\text { economic } \\
\text { Status } \\
\text { (SES) }\end{array}$} & \multirow{5}{*}{$\begin{array}{l}Y 12 \& \\
Y 13 \& \\
Y 14\end{array}$} & $\begin{array}{l}\text { Finish homework even if } \\
\text { dislike doing so \& Finish } \\
\text { homework even it is } \\
\text { time-consuming \& Go to } \\
\text { school whenever } \\
\text { possible }\end{array}$ \\
\hline & & 1=Strongly disagree \\
\hline & & 2=Somewhat disagree \\
\hline & & $3=$ Somewhat agree \\
\hline & & 4=Strong agree \\
\hline & \multirow{10}{*}{$X 1 \& X 2$} & $\begin{array}{l}\text { Mother's \& Father's } \\
\text { education level }\end{array}$ \\
\hline & & $1=$ None \\
\hline & & $\begin{array}{l}2=\text { Finished elementary } \\
\text { school }\end{array}$ \\
\hline & & $\begin{array}{l}3=\text { =Junior high school } \\
\text { degree }\end{array}$ \\
\hline & & $\begin{array}{l}4=\text { Technical secondary } \\
\text { school or technical } \\
\text { school degree }\end{array}$ \\
\hline & & $\begin{array}{l}5=\text { Vocational high } \\
\text { school degree }\end{array}$ \\
\hline & & $\begin{array}{l}6=\text { Senior high school } \\
\text { degree }\end{array}$ \\
\hline & & $7=$ Junior college degree \\
\hline & & $8=$ Bachelor degree \\
\hline & & $\begin{array}{l}9=\text { Master degree or } \\
\text { higher }\end{array}$ \\
\hline & \multirow{10}{*}{ X3 \& X4 } & $\begin{array}{l}\text { Mother's \& Father's } \\
\text { occupation }\end{array}$ \\
\hline & & $\begin{array}{l}1=\text { Unemployed or laid- } \\
\text { off worker }\end{array}$ \\
\hline & & $2=$ Peasant \\
\hline & & $3=$ Self-employed worker \\
\hline & & $\begin{array}{l}\text { 4=Ordinary staff or } \\
\text { worker in business or } \\
\text { service industry }\end{array}$ \\
\hline & & $\begin{array}{l}5=\text { Ordinary staff or } \\
\text { worker in production or } \\
\text { manufacturing industry }\end{array}$ \\
\hline & & $\begin{array}{l}6=\text { Technical worker } \\
\text { (including driver) }\end{array}$ \\
\hline & & $\begin{array}{l}\text { 7=Teacher, engineer, } \\
\text { doctor, lawyer }\end{array}$ \\
\hline & & $\begin{array}{l}\text { 8=Middle/Senior } \\
\text { management personnel } \\
\text { of } \\
\text { enterprises/corporations }\end{array}$ \\
\hline & & $\begin{array}{l}\text { 9=Government official, } \\
\text { staff of public } \\
\text { institutions, civil servant }\end{array}$ \\
\hline
\end{tabular}

Table 2 reported the distribution and descriptive information of the sample.

Table 2. Descriptive statistics of variables $(\mathrm{N}=6972)$

\begin{tabular}{|c|c|c|c|}
\hline $\begin{array}{l}\text { Variable } \\
\text { Name }\end{array}$ & Observed Variable & Mean & $\begin{array}{l}\text { Std. } \\
\text { Dev. }\end{array}$ \\
\hline Y1 & $\begin{array}{l}\text { Chinese Exam } \\
\text { Result }\end{array}$ & 70.70 & 9.42 \\
\hline Y2 & $\begin{array}{l}\text { Mathematics Exam } \\
\text { Result }\end{array}$ & 70.68 & 9.59 \\
\hline Y3 & English Exam Result & 70.72 & 9.56 \\
\hline Y4 & Cram School (1 - 2) & 1.67 & 0.47 \\
\hline Y5 & $\begin{array}{l}\text { Total cost of cram } \\
\text { school }\end{array}$ & 1196 & 4314.92 \\
\hline Y6 & Senior teacher ratio & 0.21 & 0.16 \\
\hline Y7 & $\begin{array}{l}\text { School regional } \\
\text { Ranking }(1-5)\end{array}$ & 4.01 & 0.73 \\
\hline Y8 & $\begin{array}{l}\text { School facilities (1 - } \\
3 \text { ) }\end{array}$ & 2.15 & 0.40 \\
\hline Y9 & $\begin{array}{l}\text { Giving instruction on } \\
\text { homework }(1-4)\end{array}$ & 2.07 & 1.11 \\
\hline Y10 & $\begin{array}{l}\text { Checking up } \\
\text { homework }(1-4)\end{array}$ & 2.44 & 1.17 \\
\hline Y11 & $\begin{array}{l}\text { Discuss with children } \\
(1-3)\end{array}$ & 2.16 & 0.56 \\
\hline Y12 & $\begin{array}{l}\text { Finish homework } \\
\text { even id dislike doing } \\
\text { so(1 - 5) }\end{array}$ & 3.32 & 0.84 \\
\hline Y13 & $\begin{array}{l}\text { Finish homework } \\
\text { even it is time- } \\
\text { consuming }(1-5)\end{array}$ & 2.44 & 1.17 \\
\hline Y14 & $\begin{array}{l}\text { Go to school } \\
\text { whenever possible (1 } \\
-5)\end{array}$ & 2.07 & 1.11 \\
\hline $\mathrm{X} 1$ & $\begin{array}{l}\text { Mother's Education } \\
(1-9)\end{array}$ & 3.82 & 1.96 \\
\hline $\mathrm{X} 2$ & $\begin{array}{l}\text { Father's Education (1 } \\
\text { - 9) }\end{array}$ & 4.19 & 1.96 \\
\hline X3 & $\begin{array}{l}\text { Mother's Occupation } \\
(1-9)\end{array}$ & 3.73 & 2.10 \\
\hline $\mathrm{X} 4$ & $\begin{array}{l}\text { Father's Occupation } \\
(1-9)\end{array}$ & 4.48 & 2.23 \\
\hline
\end{tabular}

\subsection{Analysis Method}

Since we need to measure the relationships between latent variables and observed variables, and among latent variables, AMOS 23 was used to set the structural equation model. Referring to our analysis framework (figure 1), we set up our structural equation model as in the following figure (figure 2). 


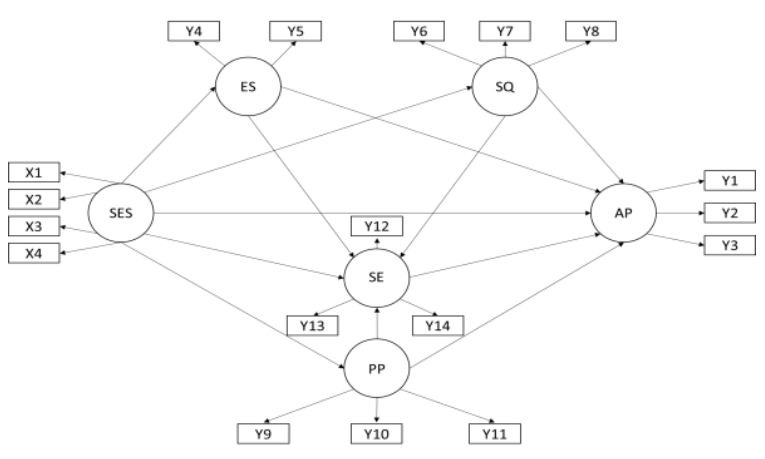

Figure 2 Setting up the structural equation model

The mechanism of the impact of socio-economic status (SES) on academic performance is extremely complicated. In this study, the personal study effort of students is conceived as playing a crucial role as it can directly affect their academic performance. Through the mediation of study effort, however, education service and school quality can also affect academic performance.

\section{RESULTS}

\subsection{Model Fit}

Evaluating the structural equation's degree of fit provides the basis for explaining the relationships between variables. In general, absolute fit indices, incremental fit indices, and parsimony fit indices are the main indicators used to evaluate the accuracy and fit of the model [23].

Absolute fit indices determine how well an a priori model fits the sample data and demonstrates which proposed model has the most superior fit [24]. Such indices include Goodness-of-Fit Index (GFI), Adjusted Goodness-of-Fit Index (AGFI), and Root Mean Square Error of Approximation (RMSEA). These measures provide the most fundamental indications of how well the proposed theory fits the data. Although Chi-square and Chi-square/Degree of freedom are the most common absolute fit indicators, their accuracy is subject to the size of sample and extremely unstable. These methods are therefore not suitable in this study, where sample size reaches around 7,000.

Incremental fit indices are a group of indices that do not use the chi-square in its raw form but compare the chi-square value against a baseline model. For these models, the null hypothesis is that all variables are uncorrelated [25]. Such models include the Normed-Fit Index (NFI), Relative-Fit Index (RFI), Incremental-Fit Index (IFI), Tucker-Lewis Index (TLI), and Comparative Fit Index (CFI). Having a nearly saturated, complex model means that the estimation process is dependent on the sample data. This results in a less rigorous theoretical model that paradoxically produces better fit indices [26]. To overcome this problem, the Parsimony Goodness-ofFit Index (PGFI) and the Parsimonious Normed-Fit Index
(PNFI) are developed. Details of model fit indices can be found as follows (table 3).

Table 3 Model Fit Indices

\begin{tabular}{|l|l|l|l|}
\hline \multicolumn{2}{|l|}{ Model Fit Indices } & Result & $\begin{array}{l}\text { Acceptable } \\
\text { Threshold } \\
\text { Levels (Hooper. } \\
\text { Et al., 2008) }\end{array}$ \\
\hline \multirow{4}{*}{$\begin{array}{l}\text { Absolute } \\
\text { Fit Indices }\end{array}$} & GFI & 0.974 & $>0.95$ \\
\cline { 2 - 4 } & AGFI & 0.963 & $>0.95$ \\
\cline { 2 - 4 } & RMSEA & 0.046 & $<0.07$ \\
\hline \multirow{4}{*}{$\begin{array}{l}\text { Incremental } \\
\text { Fit Indices }\end{array}$} & NFI & 0.946 & $>0.90$ \\
\cline { 2 - 4 } & RFI & 0.931 & $>0.90$ \\
\cline { 2 - 4 } & IFI & 0.949 & $>0.90$ \\
\cline { 2 - 4 } & TLI & 0.935 & $>0.90$ \\
\cline { 2 - 4 } & GFI & 0.949 & $>0.90$ \\
\hline $\begin{array}{l}\text { Parsimony } \\
\text { Fit Indices }\end{array}$ & PGFI & 0.681 & $>0.50$ \\
\cline { 2 - 4 } & PNFI & 0.744 & $>0.50$ \\
\hline
\end{tabular}

\subsection{Measurement Model 6.2}

Table 4 reported the relationships between observed variables and latent variables. According to the results, the standardized regression weights are all statistically significant; the majority of them reached 0.45 , meaning that observed variables have relatively high validity that well measured the latent variables. It is noteworthy that the regression weights of "senior teacher ratio" and "school facilities", which measure school quality, did not achieve the threshold of 0.45 . This indicates that these factors fail to reflect the quality of the school. We therefore expect further studies to make improvements.

Table 4 Measurement model

\begin{tabular}{|c|c|c|c|c|}
\hline \begin{tabular}{|l} 
Latent \\
Variable
\end{tabular} & $\begin{array}{l}\text { Variable } \\
\text { Name }\end{array}$ & Observed Variable & $\begin{array}{l}\text { Standardized } \\
\text { Regression } \\
\text { Weights }\end{array}$ & $\begin{array}{l}\text { Squared } \\
\text { Multiple } \\
\text { Correlations } \\
\end{array}$ \\
\hline \multirow{3}{*}{$\begin{array}{l}\text { Academic } \\
\text { Performance }\end{array}$} & Y1 & $\begin{array}{l}\text { Chinese Exam } \\
\text { Result }\end{array}$ & 0.788 & 0.620 \\
\hline & Y2 & $\begin{array}{l}\text { Mathematics Exam } \\
\text { Result }\end{array}$ & $\prod_{\star \star \star}^{0.751}(0.017)$ & 0.562 \\
\hline & Y3 & $\begin{array}{l}\text { English Exam } \\
\text { Result }\end{array}$ & $\int_{\star \star \star *}^{0.870}(0.018)$ & 0.757 \\
\hline \multirow{2}{*}{$\begin{array}{l}\text { Education } \\
\text { Service }\end{array}$} & Y4 & Cram School $(1-2)$ & 0.808 & 0.654 \\
\hline & Y5 & $\begin{array}{l}\text { Total cost of cram } \\
\text { school }\end{array}$ & $\begin{array}{l}0.473 \\
(278.787) * \star *\end{array}$ & 0.224 \\
\hline \multirow{3}{*}{$\begin{array}{l}\text { School } \\
\text { Quality }\end{array}$} & Y6 & Senior teacher ratio & 0.295 & 0.087 \\
\hline & Y7 & $\begin{array}{l}\text { School regional } \\
\text { Ranking }(1-5)\end{array}$ & $\int_{\star \star \star \star}^{0.576}(0.900)$ & 0.332 \\
\hline & Y8 & $\begin{array}{l}\text { School facilities (1 - } \\
\text { 3) }\end{array}$ & $0.011(0.151) *$ & 0.00 \\
\hline \multirow{2}{*}{$\begin{array}{l}\text { Parent } \\
\text { Participation }\end{array}$} & Y9 & $\begin{array}{l}\text { Giving instruction } \\
\text { on homework }(1-4)\end{array}$ & 0.846 & 0.716 \\
\hline & $Y 10$ & $\begin{array}{l}\text { Checking up } \\
\text { homework }(1-4)\end{array}$ & $\int_{\star \star \star}^{0.742}(0.035)$ & 0.551 \\
\hline
\end{tabular}




\begin{tabular}{|c|c|c|c|c|}
\hline \multirow{3}{*}{ Study Effort } & Y11 & $\begin{array}{l}\text { Finish homework } \\
\text { even if dislike doing } \\
\text { so }(1-5)\end{array}$ & 0.752 & 0.623 \\
\hline & Y12 & $\begin{array}{l}\text { Finish homework } \\
\text { even it is time- } \\
\text { consuming }(1-5)\end{array}$ & $\int_{\star \star \star *}^{0.789}(0.082)$ & 0.565 \\
\hline & Y13 & $\begin{array}{l}\text { Go to school } \\
\text { whenever possible } \\
(1-5)\end{array}$ & $\prod_{\star \star \star}^{0.520}(0.021)$ & 0.270 \\
\hline \multirow{4}{*}{$\begin{array}{l}\text { Socio- } \\
\text { economic } \\
\text { Status }\end{array}$} & $\mathrm{X} 1$ & $\begin{array}{l}\text { Mother's Education } \\
(1-9)\end{array}$ & 0.826 & 0.630 \\
\hline & X2 & $\begin{array}{l}\text { Father's Education } \\
(1-9)\end{array}$ & $0.793(0.015)$ & 0.682 \\
\hline & X3 & $\begin{array}{l}\text { Mother's } \\
\text { Occupation (1 - 9) }\end{array}$ & $0.582(0.016)$ & 0.339 \\
\hline & X4 & $\begin{array}{l}\text { Father's Occupation } \\
(1-9)\end{array}$ & $0.572(0.017)$ & 0.327 \\
\hline
\end{tabular}

\subsection{Path analysis of the impact of SES on academic performance 6.3}

Figure 3 and table 5 report the relationship between latent variables and their corresponding results.

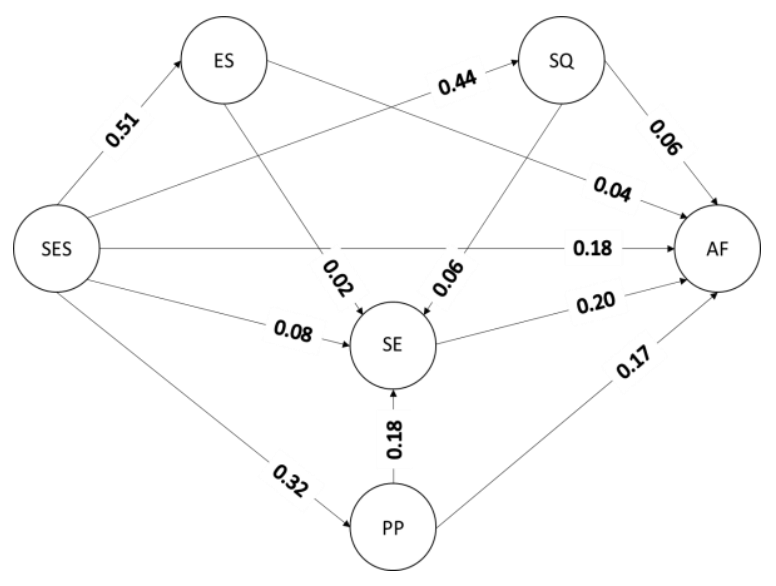

Figure 3 Path of SES and academic performance

Table 5 Path index of the impact of SES on academic performance

\begin{tabular}{|c|c|c|c|c|c|c|c|c|}
\hline & $\begin{array}{l}\text { Education } \\
\text { Service }\end{array}$ & $\begin{array}{l}\text { School } \\
\text { Quality }\end{array}$ & $\begin{array}{c}\text { Parent } \\
\text { Participation }\end{array}$ & Study Effort & $\begin{array}{c}\text { Academic } \\
\text { Performance }\end{array}$ & $\begin{array}{c}\text { Chinese } \\
\text { (Chn) }\end{array}$ & $\begin{array}{l}\text { Mathematics } \\
\text { (Mat) }\end{array}$ & English (Eng) \\
\hline $\begin{array}{l}\text { Socio- } \\
\text { economic } \\
\text { Status } \\
\text { (SES) }\end{array}$ & $\int_{\star \star \star}^{0.505}(0.004)$ & $\mid \begin{array}{l}0.444 \\
(0.001)^{* * *}\end{array}$ & $\mid \begin{array}{l}0.328 \\
* * \star\end{array}$ & $\begin{array}{l}-0.082 \\
* * *\end{array}$ & $0.180(0.101)^{\star \star \star}$ & & & \\
\hline $\begin{array}{l}\text { Education } \\
\text { Service } \\
\text { (ES) }\end{array}$ & & & & $0.021(0.032)$ & $0.004(0.083)$ & & & \\
\hline $\begin{array}{l}\text { School } \\
\text { Quality } \\
\text { (SQ) }\end{array}$ & & & & $0.022(0.032)$ & $0.056(3.786)$ ** & & & \\
\hline $\begin{array}{l}\text { Parent } \\
\text { Participati } \\
\text { on } \\
\text { (PP) }\end{array}$ & & & & $\left\{\begin{array}{l}0.180 \\
(0.011)^{\star * \star}\end{array}\right.$ & $0.173(0.126)^{* * *}$ & & & \\
\hline $\begin{array}{l}\text { Study } \\
\text { Effort } \\
\text { (SE) }\end{array}$ & & & & & $0.202(0.185)^{* \star *}$ & & & \\
\hline $\begin{array}{l}\text { Academic } \\
\text { Performan } \\
\text { ce } \\
\text { (AF) }\end{array}$ & & & & & & $\mid \begin{array}{l}0.788 \\
\star \star \star \star\end{array}$ & $\int_{* \star \star}^{0.751}(0.017)$ & $\int_{\star \star \star}^{0.870}(0.018)$ \\
\hline $\begin{array}{l}\text { Explained } \\
\text { Variance } \\
\text { Ratio of } \\
\text { Structural } \\
\text { Equation } \\
(\%)\end{array}$ & 25.5 & 19.7 & 10.8 & 1.9 & 19.5 & 62.1 & 56.4 & 75.7 \\
\hline
\end{tabular}

In general, this study explained $25.5 \%$ of variance in educational services, $19.7 \%$ of variance in school quality, $10.8 \%$ of variance in parental participation, $1.9 \%$ of study effort and $19.5 \%$ of variance in students' academic performance.

\subsection{SES and Education Resources}

The scarcity of quality school resources determines the intensity of competition. From figure 3 and table 5 we can see that the coefficient of the impact of SES on students' school quality is 0.44 . This indicates that every increase of unit in SES will lead to an increase of 0.44 
units in school quality. This shows that in the stage of compulsory education, students with higher socioeconomic status still have higher chances to attend better schools even though the government has taken many steps to alleviate this phenomenon including forbidding choosing of schools, random allocation of school placements, and neighbourhood admission.

Separate from the mechanism of access to good quality schools, extracurricular remedial classes are educational services provided by the market, which can be freely purchased by families. The mechanism affecting their access is mainly market access along with families' willingness to buy and ability to pay. The result of this study shows that the coefficient of the impact of SES on education service is 0.505 , higher than the coefficient of school quality. These two results support the first hypothesis of this study which posits that students from families with high socio-economic status have access to higher quality education resources.

\subsection{SES and Parent Participation}

Although Chinese parents generally have high expectations for their children's education, parents with different socio-economic statuses experience varying constraints in their ability to provide behavioural support for their children's education (such as discussing with their children, checking homework, etc.) [27]. Figure 3 and table 5 show that SES explained $10.8 \%$ of variance in parent participation with a coefficient of 0.328 . The theory of cultural capital suggests that although most parents recognize the importance of education, families with different socio-economic statuses create different learning environments [28]. This result supports our second hypothesis, that higher socio-economic status of the family leads to higher educational participation by their children.

\subsection{SES, Education Resources, Parental Participation, and Study Effort}

High-quality schools not only have excellent teachers, but also "better" students. Peer's behaviours significantly affect students' study effort. However, the results do not reveal a clear correlation between school quality and student study effort. Thus, hypothesis $3 \mathrm{~b}-$ that better schools lead children to have a more active study effort - is not supported. One possible explanation for this finding is the system of "class division" which prevails in Chinese education. In this system, students are allocated to different classes in accordance with their academic performance. Key classes are usually assigned the best teachers and best students, who create an intense atmosphere of study. By contrast, "bad" classes usually assemble students with the worst academic performance and delinquent conduct. The quality differentiation between classes in these conditions is significant [29].
Therefore, it is possible that the class quality rather than over school quality has a greater effect on students' study effort.

Our study found that there is no clear correlation between access to educational services and study effort. Hypothesis $3 \mathrm{c}$, which predicted that the more educational services a child receives, the more active their study effort, is not supported. One possible explanation for this non-correlation is that the practice of using additional educational services is too commonplace for it to have any difference on study effort, and that intense cram school study can negatively affect students study motivation in periods of normal study [30].

The formation of children's study effort and learning habits cannot be separated from the influence of their parents. Figure 3 and table 5 show that family socioeconomic status has a significant negative impact on children's study effort: the higher the family socioeconomic status, the lower the children's study effort. We additionally found that parents' educational participation has a significant positive effect on children's study effort: the more parents' educational participation, the more active children's study effort. This finding supports our hypothesis $3 \mathrm{a}$, which anticipated that when parents are more involved in education, their children will be more active in learning.

\subsection{Education Resources, Parental Participation, Study Effort, and Academic Performance}

Figure 3 and table 5 show that SES is positively correlated to academic performance with a coefficient of 0.18 . Every increase of unit in SES will lead to an increase of 0.18 units of academic performance. Educational services, however, do not have a statistically significant relationship with academic performance. This may due to the over-prevalence of cram school among students. According to descriptive statistics (table 2), around 67\% of students attend cram school. The specification of the cram school market and the exam-oriented system in China mean that all types of students, even those with excellent academic performance, will attend cram school seeking to be the "cream of the crop" [31]. Cram school is not only students with poor academic performance seeking improvement. Therefore, hypothesis $4 \mathrm{~b}-$ the more market-based educational services children access, the better their academic performance - is not supported.

School quality also positively affects students' academic performance with a coefficient of 0.056 . Our hypothesis $4 \mathrm{a}$, which predicted that children who attend better schools have better academic performance, is supported. It is important to note, however, that the system of "class division" discussed above generates significant differences in quality within schools. We expect that further studies can better capture the 
interaction of this heterogeneity with socio-economic status.

Our statistics also found that parental participation has a positive effect on academic performance. This finding supports Coleman's conclusion that parents' educational participation not only indirectly affects children's academic achievement by influencing their learning attitudes and behaviours, but also directly affects children's academic performance. Hypothesis $4 \mathrm{a}$, that higher levels of parental involvement leads to better academic performance, is therefore supported. Finally, as students' study effort is positively correlated to their academic performance with a coefficient of 0.20 , our hypothesis 5 is supported.

\section{DISCUSSION}

These results lead to five conclusions. First, students' socio-economic status has a positive impact on their academic performance. Second, students from families with higher socio-economic status have access to higher quality education resources, including high-quality schools and market-based educational services. Third, parents in families with high socio-economic status participate in their children's education more readily. Fourth, parents' participation has a positive impact on students' study effort. Fifth, school quality, parent participation, and study effort are positively correlated to students' academic performance. These five conclusions all reflect the impact of socio-economic status on academic performance. Specifically, these results reveal that family background affects academic performance through two pathways: direct access and behavioural support. Families use their socio-economic resources to compete and purchase high-quality educational resources while providing educational participation and behavioural support that cultivates children's learning interests and habits. Each of these mechanisms influences children's academic achievement.

Theories of capital help to explain these paths. ${ }^{\mathrm{T}}$ he theory of human capital, which understands education as an important investment in human capital views the "cost-benefit" measurement as the main principle of family education investmen ${ }^{t}$. According to this view, the difference in children's educational achievements is mainly caused by the amount of family investment in education [32].

The family model proposed by Becker views children's education, including their academic performance, as a part of the family utility function. Parents maximize the utility of their children's education by choosing different combinations of children's education and other commodities, thus determining children's educational achievement. Constrained by family resources, parents in poor families often invest less in their children's education, which affects their children's academic achievements. Cultural capital theory emphasizes the influence of family cultural resources and cultural atmosphere on children's educational expectations and academic performance. Compared with families with insufficient cultural capital, parents with rich cultural capital usually have a better understanding of school education rules. Such families tend to invest more cultural resources that can cultivate children's educational expectations and learning interests, helping children to master the school curriculum and achieve excellent academic results [33]. The social capital theory emphasizes the influence of parents' educational participation on children's study effort and academic achievement. Parents of higher socio-economic status tend to be more involved in their children's learning activities, pay more attention to communication with schoolteachers and other parents, reduce truancy and risky behaviour, and thus improve their children's academic performance [34].

Due to the differences in the allocation of educational resources among urban and rural areas, regions, and schools, the quality of schools is often taken as an important influencing factor when discussing the relationship between family background and educational acquisition. Key schools usually employ excellent teachers and enrol excellent students, which has an important impact on children's access to the next stage of education. Families with relatively high socio-economic status will make use of various resource advantages to strive for access to high-quality educational resources for their children and thus increase the probability of obtaining good educational resources in the next stage [35]. According to studies, the socio-economic status of parents has an important influence on the quality of the school children attend: the higher the socio-economic status of the family, the higher quality of school the children attend [36].

Scholars from many different theoretical perspectives pay attention to the pathways and mechanisms by which family socio-economic status affects children's academic achievement. Those using human capital theory emphasise family economic resources as a means to invest in education and children's academic achievement while those focused on cultural capital and social capital theory pay more attention to the parents' level of education, their participation in education, and differences in school quality. In fact, the influence of any factor is not independent. Family financial resources, family atmosphere, and school quality are all important. The problem is that these are exogenous factors that need to be examined alongside the study effort of the children being educated and the children's academic achievement.

\section{CONCLUSION}

This paper examined the pathways by which socioeconomic status impacts students' academic performance 
by studying 6,972 students around China. By employing the structural equation model, this study found that socioeconomic status affects students' academic performance as higher status allows parents to provide high-quality educational resources and empowers parents to participate in their children's education more often, thus positively affecting their study effort. This finding of these two influential paths supplements the existing research on family background and educators' educational attainment and provides evidence that can support efforts to reduce class-based differences in children's academic achievement in compulsory education, to improve the overall level of human capital in China, and promote equity in education.

Education levels within the family are extremely important to children's academic performance. Parents with poor socio-economic conditions can become involved in the educational process of their children by caring for and supervising their children's academic performance, by actively corresponding with teachers about their children's academic performance, and by cultivating healthy learning habits in their children. These efforts will help improve students' academic performance, reduce the impact of the family's socioeconomic status on their children's academic achievements, and thereby reduce the class differences in education and in the labour market.

Schools can improve students' academic achievements in two main ways. They can strive to improve teachers' knowledge level and teaching skills while encouraging parents to create a positive educational atmosphere both at school and at home. Both these actions can enhance children's interest in learning and help them cultivate healthy learning habits. At a national level, relevant departments should supervise and run every school in the compulsory education stage to the best of their abilities, improve school education facilities, enhance teacher quality, and achieve a balanced allocation of educational resources. In this way, societies can reduce the impact of school-based factors on children's academic achievements.

\section{ACKNOWLEDGMENTS}

I would like to show my deepest gratitude to my mother Dr. You Wu and Professor Liam Gearon for their constant guidance in every stage of the writing of this paper. Further, I sincerely appreciate Ximing Chen from Cetus Talk for her generous help on this paper's feedback and layout. Without all enlightening instruction and impressive kindness, I could not have complete this paper.

\section{REFERENCES}

[1] Heckman,James J. The Economics of Inequality: The Value of Early Childhood Education, American
Educator, 2011, 35( Spring)

[2] Yang, Dongping. The Ideal and Reality of Educational equity in China. Beijing: Peking University Press, 2006

[3] Cheng, H. Inequality in Basic Education in China: A Comprehensive Review. International Journal of Educational Policies. Vol.3(2),2009, pp.81-106

[4] Zhao, H. The Investigation of the Influence Factors of Students' achievement in Junior High School - the Analysis of the Regression Model. 2011, Doctoral Dissertation, East China Normal University

[5] Li, ZL \& Qiu, ZQ. Family Background and Children's Academic Performance: Evidence from the Compulsory Education in China. Sociological Studies, 2016, 4: 121-144

[6] Young, N., \& Hannum, E. Childhood Inequality in China: Evidence from Recent Survey Data (20122014). The China Quarterly, 2018, 236: 1063-1087.

[7] Li, Fangyuan. Survey on the Relationship between Academic Achievement and Family Capital (Master Dissertation), Hubei University, 2011

[8] Parke.R.D. Review of Child Development Research 7: the Family. Chicago: University of Chicago Press, 1984

[9] Kiesling, HJ. The relationship of school inputs to public school performance in New York Sate. Washington.DC:U.S Department of Health, Education, and Welfare, 1969, Office of Education, 233

[10] Jencks et al. A Reassessment of the Effect of Family and Schooling in America. New York: Basic Books, 1972

[11] Sewell WH.and Hauser,R. Causes and consequences of higher education: Models of the status attainment process.In W.H.Sewel,RM.Hauser, and D.L.Featherman(eds.).Schooling and achievement. New York: Academic Press, 1976

[12] Datcher-Loury, Linda. Effects of Mother's Home Time on Children's Schooling, The Review of Economics and Statistics, MIT Press, 1988, vol. 70(3): 367-373

[13] Laosa, L.M. School, occupation, culture, and family: The impact of parental schooling on the parent-child relationship. Journal of Educational Psychology, 1982, 74: 791-827.

[14] Levine, D.U. Society and education (9th Ed.). Boston: Allyn and Bacon, 1996

[15] Yang, Dongping. A Research into the Senior High School Students' Social-class-delamination and 
Education Acquisition. Tsinghua Journal of Education, 2006, 3:52-59

[16] Wu, Kangning. Sociology of Education. Beijing: Renmin Education Press, 1998

[17] Lu, Zhiquan. The effects of family contributing factors on school achievement, Chinese Journal of Behavioral Medical Science, 2000, 9:12-15

[18] Dong, Zefang. The Influence of Family Environment on Academic Success - An investigation and analysis of the family environment of Chinese Mathematical Olympians in 1991, Educational Research and Experiment, 1991, 2:1519

[19] Liu, Jingming. The State, Social Class and Education. Beijing: Renming University Press, 2005

[20] Yang, Dongping. The Ideal and Reality of Educational equity in China. Beijing: Peking University Press, 2006

[21] Yu, L. Luo, S. The Influence of Family Capital on the Learning Quality of Disadvantaged Children: The Intermediary of Family Psychological Intervention, Studies in Early Childhood Education, 2020, 9: 59-68

[22] Li, ZL \& Qiu, ZQ. Family Background and Children's Academic Performance: Evidence from the Compulsory Education in China. Sociological Studies, 2016, 4: 121-144

[23] Kline, Rex B. Principles and Practice of Structural Equation Modeling. Guilford: Guilford Press, 2015

[24] Hooper, Daire. Et al. Structural Equation Modelling: Guidelines for Determining Model Fit, Electronic Journal of Business Research Methods, 2008, 6(1): 53-60

[25] McDonald, R.P. and Ho, M.-H.R. Principles and Practice in Reporting Statistical Equation Analyses, Psychological Methods, 2002, 7 (1), 64-82

[26] Mulaik, S.A., James, L.R., Van Alstine, J., Bennet, N., Lind, S., and Stilwell, C.D. Evaluation of Goodness-of-Fit Indices for Structural Equation Models, Psychological Bulletin, 105 (3), 1989, 43045.

[27] Hong, Yanbi \& Qian, Minhui. Social Stratification and Educational Equality in China:A Critic Review, China Agricultural University Journal of Social Sciences Edition, 2008, 25(4):64-76

[28] Chen, Gang. The Education Predicament and Countermeasures of the Urban Migrant Children under the Perspective of Cultural Capital, Research in Educational Development, 2011, 31(23):8-13
[29] Li, Xianjun. The key class system and educational equity in junior middle school, Education Research Monthly, 2008, 1:66-68

[30] Li, Caixia. Why are extracurricular remedial classes prevalent in primary and secondary schools? Institute of Public Policy, South China University of Technology, 2020. Available at http://www.ipp.org.cn/index.php/home/blog/single/i d/639.html [Accessed at 24 December 2020]

[31] Jiang, Guohua. Competition in Education: "Top Notching" or Innovation?, 2006, Democracy \& Science, 5:58-59

[32] Becker,Gary S. Human Capital: A Theoretical and Empirical Analysis,with Special Reference to Education. Chicago: University of Chicago Press, 1964

[33] Bourdieu,Pierre \& Jean-Claude Passeron Reproduction in Education,Society and Culture ( 2nd edition) .Trans. by Richard Nice. Calif: Sage Publications, 1990

[34] Coleman,James S. Social Capital in the Creation of Human Capital. American Journal of Sociology, 1988, 94

[35] Li, Y. Institutional Change and Educational Inequality: Mechanisms in Educational Stratification in Urban China (1966-2003), Social Sciences in China, 2006, 4: 97-109

[36]Wen, DM. School Choice in Chinese Urban Compulsory Education and Its Impact on Disadvantage Groups, Peking University Education Review, 2006, 2:12-23 